\title{
Evidence inconclusive - comment on article by Schoenfeld et al
}

\author{
David J. Beale
}

\begin{abstract}
This article comments on the study by Schoenfeld, et al. entitled "The effect of protein timing on muscle strength and hypertrophy: a meta-analysis" and discusses how the methodology led to inconclusive results.
\end{abstract}

Recently, Journal of the International Society of Sports Nutrition published a meta-analysis to determine whether consuming protein in and around a workout enhanced strength and muscular development [1]. In the paper, the authors argue that the results refute the claim that protein intake timing around training sessions positively influences strength and muscular adaptations. However, most of the studies chosen for analysis were not even suitable to answer the study question.

Twenty of the 23 studies in the meta-analysis compared protein supplement to placebo and of these 20 studies none matched total daily protein intake between groups. Therefore, the studies afford no reasonable assessment of whether timing of protein intake around exercise is beneficial because higher total daily protein intake is a confounding factor. Only 3 studies in the meta-analysis would be applicable to the question of protein timing [2-4]. This is because the studies compared protein supplement intake in and around workouts to supplement intake some time before and after. The sample sizes were small and the 3 studies comprised a total of 77 subjects. The authors' assertion that the study had "good statistical power" due to the sample size of about 500 subjects is belied by the use of only 3 relevant studies.

\section{Funding}

No funding provided for this article.

\section{Author contributions}

David J. Beale was responsible for the sole content of this article.

\section{Competing interests}

The author declares that he has no competing interests.

\section{Correspondence: dbeale01@gmail.com}

OptumRx, Home Delivery, Pharmacist, United Health Group, 2300 Main St, Irvine, CA 92614, USA

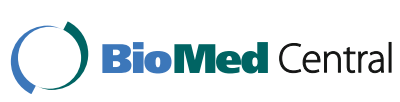

Received: 6 September 2016 Accepted: 6 October 2016

Published online: 10 October 2016

References

1. Schoenfeld BJ, Alan Albert A, Krieger JW. The effect of protein timing on muscle strength and hypertrophy: a meta-analysis. J Int Soc Sports Nutr. 2013;10.1:1.

2. Cribb PJ, Hayes A. Effects of supplement-timing and resistance exercise on skeletal muscle hypertrophy. Med Sci Sports Exerc. 2006;38.11:1918-25.

3. Hoffman JR, et al. Effect of protein-supplement timing on strength, power, and body-composition changes in resistance-trained men. Int I Sport Nutr Exerc Metab. 2009;19.2:172-85.

4. Wycherley TP, et al. Timing of protein ingestion relative to resistance exercise training does not influence body composition, energy expenditure, glycaemic control or cardiometabolic risk factors in a hypocaloric, high protein diet in patients with type 2 diabetes. Diabetes Obes Metab. 2010;12.12:1097.

\footnotetext{
Submit your next manuscript to BioMed Central and we will help you at every step:

- We accept pre-submission inquiries

- Our selector tool helps you to find the most relevant journal

- We provide round the clock customer support

- Convenient online submission

- Thorough peer review

- Inclusion in PubMed and all major indexing services

- Maximum visibility for your research
}

Submit your manuscript at www.biomedcentral.com/submit (c) 2016 The Author(s). Open Access This article is distributed under the terms of the Creative Commons Attribution 4.0 International License (http://creativecommons.org/licenses/by/4.0/), which permits unrestricted use, distribution, and reproduction in any medium, provided you give appropriate credit to the original author(s) and the source, provide a link to the Creative Commons license, and indicate if changes were made. The Creative Commons Public Domain Dedication waiver (http://creativecommons.org/publicdomain/zero/1.0/) applies to the data made available in this article, unless otherwise stated. 